O problema, tal como se coloca entre nós, não pode ser abordado através do ponto de vista marxista; não temos uma infra-estrutura produzindo uma superestrutura ideológica; o que temos é uma superestrutura ideológica que se transporta para o Brasil por intermédio de indivíduos que perderam verdadeiramente o seu grupo. Na terra estranha, a partir da ideologia religiosa que foi transportada, é que se vai formar o novo grupo, que assim se estrutura ao contrário da tese marxista: a superestrutura produz uma infra-estrutura...

Como se vê, também não segue o Autor uma perspectiva culturalista; a sobrevivência da religião negra não é buscada em si mesma, mas explicada pela organização social que aqui se criou e na qual encontrou então seu ponto de apoio. No estudo das civilizações em presença, Roger Bastide toma sempre como base e ponto de referênia as configurações estruturais dos grupos que suportam essas civilizações. E é dentro de tal preocupação constante que verifica a adequação e redefine conceitos tais como o de reinterpretação cultural, de memória coletiva, de participação, formulando também um conceito complementar dêste último, a que dá o nome de "princípio de separação" (principe de coupure).

Como se vê, trata-se de um trabalho de grande importância para o Brasil - pois arialisa fatos sociais brasileiros - e para a Sociologia em geral - um vez que revê e amplia, à luz do cotejo com a realidade social, conceitos por ela formulados.

\title{
Maria Isaura Pereira de Queiroz
}

FELíCITAS BARReTO: Danzas Indígenas del Brasil. Prólogo de Miguel León Portilla. $\mathrm{XI}+138$ págs., com 50 fotografias fora do texto. Instituto Indigenista Interamericano. México, 1960.

Esparso pela copiosa literatura sôbre aborígenes brasileiros, há um sem-número de informes sôbre as danças encontradas nas diferentes tribos. Ninguém até hoje, ao que nos consta, se deu ao trabalho de sistematizar êsses elementos no intuito de apreciá-los num quadro de conjunto, discernindo entre o que nêles haja de comum e o que de específico distinga a coreografia de tal ou qual grupo em conexão com o respectivo sistema cultural. Em certo sentido, o volume de Felícitas Barreto poderia representar um primeiro passo nessa direção ou, pelo menos, um estímulo. Infelizmente, porém, foi escrito sem o necessário preparo científico. O Instituto Indigenista Interamericano, que se incumbiu de publicá-lo, deu-lhe luxuosa apresentação material, enriquecendo-o com a reprodução de numerosas fotografias, algumas excelentes.

Declara a autora que procurou imprimir a seu trabalho dois traços característicos: "Desejo que seja o mais fiel possível e que reflita de algum modo o profundo carinho que sinto pelo indígena brasileiro". Quanto ao segundo ponto, acrescenta: "E creio estar solidária com os sentimentos, não apenas de meus compatriotas brasileiros, mas de todo homem de boa vontade, ao afirmar que é necessário incrementar a ação indigenista no sentido de impedir o desaparecimento de nossos irmãos nativos, que com suas tradições e suas danças maravilhosas nos ligam a um passado cultural que ainda sobrevive na selva". Todos os que compartilhamos dêsses sentimentos fazemos votos por que o volume contribua a seu modo para melhorar a deplorável situação em que se encontram os nossos silvícolas. No que diz respeito ao valor científico da obra, há nela muitas falhas que o comprometem sèriamente.

Numa breve introdução, escrita com viveza, e com ligeireza também, Felícitas Barreto procura delinear os contornos gerais do "mundo indígena do Brasil". Nessas 
páginas há, infelizmente, uma série de erros e de generalizações infundadas. O leitor desprevenido poderia ficar com a impressão de que as tribos índias do Brasil são tôdas pràticamente iguais. Preferível teria sido narrar ou descrever singelamente o que a autora observou em suas visitas aos diferentes grupos, mencionando sempre o nome da respectiva tribo.

E' pena também que não tenha tido oportunidade de familiarizar-se com as fontes bibliográficas indispensáveis à discussão do assunto. Alguns dos trabalhos que cita têm relação apenas remota com o texto, ao passo que muitos outros, de importância fundamental, lhe passaram despercebidos. E, com receio talvez de dar a seu livro um c.mho demasiado erudito, não estabelece, em parte alguma, conexão entre as descrições que apresenta e as fontes que consultou. Tampouco deixa entrever o que é devido a observações pessoais e o que foi respigado nos trabalhos que leu.

Entre os grupos visitados figuram, segundo o prólogo de Miguel León Portilla, os Apapokúva-Guaraní. As danças dêsses índios descreveu-as pela primeira vez Nimuendajú em seu trabalho inserto em 1914 na "Zeitschrift für Ethnologie" e que não consta da bibliografia arrolada no fim do volume. A autora situa o grupo às margens de um Rio Curuá no sul de Mato Grosso. Ora, o Curuá fica na parte setentrional dêsse Estado, e lá não existe nenhuma aldeia de Apapokúva. F. Barreto atribui a êsses índios uma dança "acyigua", que outra coisa não parece ser senão o episódio da caça a um "anguery" (assombração de defunto), narrado por Nimuendajú e que de dança não tem nada. Entre as danças da tribo figura o "joaza" (palavra interpretada errôneamente como a "parte indiferente" da alma humana), cuja descrição deixa muito a desejar, sobretudo se comparada com a que nos deixou Nimuendajú. Tudo isso logo nas primeiras páginas do livro, bastante representativas para as demais.

Em nossa opinião, o texto deveria ter sido submetido à apreciação crítica de algum especialista em etnologia brasileira, antes que se cogitasse de publicá-lo.

\section{Egon Schaden}

\section{ALTIVA PILATTI BALHANA: Santa Felicidade - Um Processo de Assimilação.} 282 págs., com 7 figs. no texto, 27 estampas e 1 mapa. Tip. João Haupt \& Cia. Ltda. Curitiba, 1958.

Apesar do grande número, da antigüidade e da importância dos imigrantes italianos nos processos econômicos que envolveram o Brasil meridional, não têm êles merecido muita atenção dos especialistas. A bibliografia sôbre êles é pobre, e nenhuma pesquisa de maior fôlego se fêz até agora. Justamente o que caracterizou êsses imigrantes foi a rapidez de seu processo aculturativo, e se isto é uma dificuldade para a realização de um estudo, é também um incentivo, uma vez que se pode pôr a nu os motivos fundamentais e os mecanismos atuantes no processo.

Esta monografia sôbre a colônia de Santa Felicidade vem acrescentar à escassa bibliografia uma pesquisa demorada e séria, fruto de longo contacto com os imigrantes concentrados em um núcleo. Temos aí uma descrição minuciosa da vida das famílias, de suas atividades rotineiras, seus êxitos, seus trabalhos e das inovações que paulatinamente as vão atingindo. O que falta é a tentativa de explicar o processo de assimilação, de esclarecer como funcionam os padrões culturais europeus e como são abandonados ou modificados. 